\title{
Probleme Dayalı Öğrenme Yöntemi ile Desteklenen 5E Öğretim Modelinin Başarı ve Tutuma Etkisi ${ }^{1}$
}

\author{
DOI: $10.26466 /$ opus.754216
}

*

\author{
Șerif Ali Değirmençay*- Figen Hun** \\ *Dr.Öğr.Üyesi , Giresun Üniversitesi Eğitim Fakültesi-Giresun/Türkiye \\ E-Posta: serifali.degirmencay@giresun.edu.tr ORCID: 0000-0003-1528-7406 \\ **Öğretmen, Kazanbey Ortaokulu,Ağrı/Türkiye \\ E-Posta figenhun70@gmail.com \\ ORCID: $\underline{0000-0002-9741-0174}$
}

$\ddot{\mathrm{O} z}$

$\mathrm{Bu}$ araştırmanın amacl; ortaokul 7. sinı öğrencilerinin, fen bilimleri dersinde "maddenin tanecikli yapısı ve karışımlar" konusunda, derinleştirme aşaması, probleme dayalı öğrenme yöntemi ile geliştirilmiş $5 E$ öğretim modelinin, öğrencilerin akademik başarn ve tutumlarna yönelik etkilerini belirlemektir. Araştırma, 2016-2017 eğitim öğretim yılı Giresun ili, Doğankent ilçesindeki 7. sinıfta öğrenim gören 40 öğrenci ile gerçekleştirilmiştir. Çalışma yarı deneysel yöntem ile gerçekleştirilmiştir. Araştırmanın uygulama süresi hem deney hem de kontrol gruplarında 3 hafta, 10 ders saati ile sinırlıdır. Veri toplama aracı olarak, deney ve kontrol gruplarına Şahin (2016) tarafindan geliştirilen KR-20 güvenirlik katsayısı .794 olarak hesaplanmıs 15 soruluk akademik başarı testi ve Fen'e Karşı Tutum Ölçeği kullanılmıştır. Verilerin analizinde; deney ve kontrol grubuna ön-son test olarak uygulanan başarı testi, bağ̆msız gruplar t testti ile analiz edilmiş ayrica her sorunun deney ve kontrol grubunda ön test ve son test ortalama değerleri incelenmiştir. Fen'e Karşı Tutum Ölçeği'nin analizi ise ön test ve son test puanlarına ilişkin bağımsız gruplar $t$ testi ile analiz edilmiştir. Araştırmanın sonucunda, başarı testi ve tutum ölçekleri son test sonuçlarına göre deney grubu lehine anlaml fark tespit edilmiştir. Bu sonuç, probleme dayalı öğrenme yöntemi ile geliştirilerek uygulanan $5 E$ öğretim modelinin, öğrenen akademik başarısında daha etkili olduğu ve tutumlarını da olumlu yönde etkilediğini göstermiştir.

Anahtar Kelimeler: Yapılandırmacı öğretim kuramı, probleme dayalı öğrenme, 5 E öğretim modeli, başarı, tutum.

\footnotetext{
${ }^{1}$ Bu çalışma, “Probleme Dayalı Öğrenme Yöntemi ile Desteklenen 5E Öğretim Modelinin Başarı ve Tutuma Etkisi" adlı yüksek lisans tezinden üretilmiştir.
} 


\title{
Effect of 5E Teaching Model Supported By Problem Based Learning on The Achievement and Attitude
}

\begin{abstract}
Purpose of this study is to identify effects of $5 E$ teaching model developed with deepening stage, problem-base learning method on academic achievement and attitudes of students with regards to the subject of "granular structure of the matter and mixtures" at the life sciences class of secondary school $7^{\text {th }}$ grade students. The research was conducted, in 2016-2017 academic year, with $407^{\text {th }}$ grade students in the province of Giresun, district of Dogankent. The study was conducted with semi experimental method. The implementation period of the research was limited to 3 weeks, 10 classes for both experiment and control group. As the data collection tool, an academic achievement test composed of 15 questions with KR-20 reliability coefficient calculated as .794, as developed by Şahin (2016) and the Scale of Attitude towards Science were used for the experiment and control groups. For the purpose of analyzing the data, the achievement test applied to experiment groups as pretest-posttest was analyzed with independent groups $t$ test, and, further, pretest and posttest average values of each question in the experiment and control group were examined. The analysis of the Scale of Attitude Towards Science was carried out with independent groups $t$ test relating to pretest and posttest points. Upon conclusion of the research, a significant difference was detected in favor of the experiment group according to posttest results of achievement test and attitude scales. This conclusion indicates that $5 E$ teaching model developed and implemented with problem-based learning method is more effective in the academic achievement of the learner and had a positive impact upon their attitudes.
\end{abstract}

Keywords: Constructivist teaching theory, problem-based learning, 5E teaching model, achievement, attitude. 


\section{Giriş}

Dünyada nüfus hızla artmakta, tüketim her geçen gün hızlanmaktadır. Buna bağlı olarak insan ihtiyaçlarını sağlamak, çağa yetişebilmek için her geçen gün yeni bir teknolojik gelişmeye gereksinim duyulmaktadır (Çepni ve Çoruhlu, 2009). Bu gelişmeleri sağlayabilmenin temeli ise düşünen, merak eden, keşfeden, sorgulayan, yeniliklere ve tüm dünyaya açık ileri görüşlü bireyler yetiştirmekten geçmektedir (Yılmaz, 2016). Burada da eğitimin önemi ortaya çıkmaktadır. Bireylerin çağın gereklerine, sürekli gelişen ve değişen teknolojiye, dünyaya ayak uydurabilmelerinin temelinde eğitim yatmaktadır (Çelik, 2010).

Eğitim süreklidir ve bireyin hayatının her alanında eğitim vardır. Burada önemli olan bireyin eğitimin merkezinde olması ve en aktif şekilde eğitimden verimli olarak faydalanabilmesidir (Uzoğlu, 2010). Günümüz eğitim sistemimizde de temel amaç bilgilerin öğrenciye aktarılması değil aksine öğrencinin bilgiye ulaşmasında ona yardımcı olmak ve ona rehberlik etmektir (Değirmençay ve Kasap, 2013). Yenilenen eğitim programları ile birlikte bu temel amaç gerçekleştirilmeye çalışılmaktadır. Bunun için geleneksel eğitimin yerine çağdaş eğitim benimsenmiş olup eğitim- öğretimin merkezine öğretmen değil öğrenci alınmıştır. Bu sebeple artık öğretmen merkezli eğitim değil onun yerine kalıı öğrenmeyi sağlayan öğrenci merkezli eğitim benimsenmiştir (Ünal ve Akay, 2017).

Fen bilimleri dersi öğretim programında da en son yenilik 2017 yllında yapılmış olup, araştırma ve sorgulamaya dayalı, kavramların öğretilmesinde farklı yöntem ve tekniklerin kullanıldığı, bireylerin fen okuryazarı olarak yetiştirilmesini benimseyen güncel bir program oluşturulmuştur. 2017 y1lında yenilenen fen bilimleri dersi öğretim programında temel amaç, merak ve keşfetme duygusunu ortaya çıkarıp öğrenciyi yaratıcı düşünmeye sevk etmektir (Y1lmaz, 2017). Fen programinun bir diğer temel hedefi ise 'fen okuryazarı' bireyler yetiştirmektir (MEB, 2017).

Fen okuryazarı bireyler yetiştirilmesi için öğretmen ve öğrencinin rolleri verilmiş olup; öğretmen, derste dikkat çekici, güdüleyici, aktif olarak öğrenciyi derse çeken, cevabı direk veren değil öğrencinin araştırıp bulmasında rehber olan kişidir (Benli Özdemir ve Arık, 2017). Öğrenci ise her daim sorgulayan, keşfeden, verilen bilgiyi ezberlemek yerine kendi zihninde anlamlandırmaya çalışmalı ve her yeni bilgiyi günlük yaşamıyla ilişkilendirmeli- 
dir (Aktamış ve Hiğde, 2017). Öğretmenin ve öğrencinin verimli bir şekilde bu rolleri derste gerçekleştirebilmesi, aynı zamanda farklı yöntem ve teknikleri kullanabilmesi için öğretim programlarında verilen kazanımlarda azalmaya gidilmiştir (Zorluoğlu, Şahintürk ve Bağrıyanık, 2017).

Bütün bu gelişmelerin gerçekleştirilmesi için öğretim programlarında belirtildiği gibi her derse uygun öğretim stratejileri ile yöntem ve tekniklerin uygulanması gerekmektedir (Şahin, 2016). 5E öğretim modeli öğretim programının da sınıf ortamında kullanmak için önerdiği modellerden biridir. Aynı zaman da fen okuryazarı bireyler yetiştirebilmek için öngördüğü modellerden biridir (Yaman ve Yalçın, 2005). Bu model yapılandırmacı öğrenme yaklaşımıyla özdeşleşmekte, MEB tarafından istenilen öğrenmelerin sağlanmasında aktif rol oynamaktadır. Ayrıca 5E öğrenme modeli sınıf ortamında farklı yöntem ve tekniklerin gerçekleşmesini de sağlanmaya imkân sunmaktadır. Farklı yöntem ve teknikler öğrencinin derse katılımını artırmakta, sınıf ortamındaki sıkıcılığı ortadan kaldırmakta ve öğrencinin birebir öğretimin içinde olduğu bir öğrenme sağlamaktadır. Böylece öğrenciler derste güdülenmekte, derse olan ilgi ve istekleri artmaktadır (Değirmençay, 2010).

Eğitim- öğretim ortamında kullanılan farklı yöntem ve tekniklerden birisi de probleme dayalı öğrenme yöntemidir (Çınar ve İlik, 2013). Probleme dayalı öğrenme yönteminde öğrenciye verilen senaryolar sayesinde öğrenci problemle karşı karşıya getirilerek çözüm yolları üretmesi istenmektedir (Dağyar ve Demirel, 2015; Yılmaz, 2016). Verilen senaryolar günlük yaşamla ilgili olup çocuğun problemin merkezine kendisini koyarak anlamlı öğrenmeler sağlaması ve edindiği bilgileri günlük yaşamla ilişkilendirmesi amaçlanmaktadır (Tosun, Şenocak ve Özeken, 2013). Senaryolara üretilen çözüm yolları sayesinde öğrencilerde yaratıcı düşünme becerileri gelişmekte araştırma ve tartışma ile de çok yönlü düşünebilmektedirler. Bu yüzden bu öğrenme yönteminin öğrencide aktif öğrenmeler sağlayacağı ve öğretmene de öğrenme ortamında kolaylıklar sunacağı düşünülmektedir (Cotič ve Zuljan, 2009).

Yapılan çalışmalar incelendiğinde; probleme dayalı öğrenme yöntemi ile ilgili olarak birçok çalışma karşımıza çıkmaktadır. Ancak probleme dayalı öğrenme yönteminin 5E öğretim modeli ile desteklenerek; derinleştirme aşamasında uygulanması ile ilgili araştırma sayısının sınırlı olduğu görülmektedir. Yapılan bu çalışmada fen bilimleri dersi öğretim programının 
öngördüğü 5E öğretim modeli ile öğrenciye merak uyandırmak, keşfetmesini sağlamak, bilgi edinmesine rehberlik etmek, derinleştirme aşamasında uygulanan probleme dayalı öğrenme yöntemi ile yeni bir problem durumuyla karşılaştırılarak daha derinlemesine anlama yeteneğini geliştirmek ve değerlendirme aşaması ile de süreç tamamlanmaktadır. Bu çalışmada; 'maddenin tanecikli yapısı ve karışımlar' gibi soyut bir konuda öğrencinin her aşamada aktif olduğu, yaparak yaşayarak daha kalıc öğrenmeler gerçekleştirmesi amaçlanmıştır. Bu kapsamda aşağıdaki sorulara cevaplar aranacaktır:

1. Maddenin tanecikli yapısı ve karışımlar konularının, probleme dayalı öğrenme yöntemi ile desteklenen 5E öğretim modeli ile işlenmesi, öğrencilerin akademik başarılarını etkilemekte midir?

2. Maddenin tanecikli yapısı ve karışımlar konularının, probleme dayalı öğrenme yöntemi ile desteklenen 5E öğretim modeli ile işlenmesi, öğrencilerin fen bilimlerine karşı tutumlarını etkilemekte midir?

\section{Yöntem}

\section{Araştırmanın Modeli}

Yapılan çalışmada ilköğretim 7. sınıf fen bilimleri dersinde; probleme dayalı öğrenme yöntemi ile desteklenen $5 \mathrm{E}$ öğretim modelinin, öğrencilerin akademik başarı ve fen bilimleri dersine karşı olan tutumların tespit etmek amaçlanmıştır. Bu bağlamda yapılan çalışmada deney ve kontrol gruplu ön test- son test içerikli yarı deneysel yöntem kullanılmıştır. Yapılan çalışmada deney ve kontrol grupları yansız atama ile belirlenmiştir. Çalışma süresince kontrol grubu ile yapılan çalı̧̧ma, fen bilimleri dersi öğretim programının ön gördüğü şekilde yürütülmüş, deney grubunda ise probleme dayalı öğrenme yöntemi ile desteklenmiş $5 \mathrm{E}$ öğretim modeline göre geliştirilmiş ders planları kullanılmıştır. Sürecin öncesinde deney ve kontrol grubuna başarı testi ve fen bilimleri tutum ölçeği uygulanmıştır.

\section{Çalışma Grubu}

Çalışma grubu Doğankent ilçesindeki bir ortaokulda öğrenim gören toplam 40 7. sınıf öğrencisinden oluşmaktadır. 2016-2017 eğitim-öğretim yılında 
gerçekleştirilen çalışmanın ders planları pilot uygulaması ise Özel Etüt Merkezinde gerçekleştirilmiştir. Çalışma; 20 kontrol, 20 deney grubunda olmak üzere toplam 40 öğrenci ile gerçekleştirilmiştir. Deney grubunda yer alan 20 öğrencimizin 12 tanesini kız öğrenciler, 8 tanesini ise erkek öğrenciler oluşturmaktadır. Kontrol grubunda yer alan 20 öğrencinin de 11 tanesini kız öğrenciler, 9 tanesini ise erkek öğrenciler oluşturmaktadır.

\section{Veri Toplama}

\section{Veri toplama araçlarn}

Araştırmada akademik başarı testi ve Fen'e Karşı Tutum Ölçeği kullanılmıştır. Öğrencilerin akademik başarılarına olan etkisini tespiti için, Şahin (2016) tarafından geliştirilen güvenirlik katsayısı KR-20 .794 olarak hesaplanmış 15 soruluk akademik başarı testi kullanılmıştır.Bu test, deney ve kontrol grubuna hem sürecin başlangicında hem de sürecin bitiminde ön-son test olarak uygulanmıştır. Böylece, uygulanan öğretim modelinin öğrencilerin akademik başarılarına olan etkisi tespit edilmiştir. Aynı zamanda, öğrencilerin fen bilimlerine yönelik tutumlarının tespiti için Nuhoğlu (2008) tarafından geliştirilen 20 soruluk tutum ölçeği kullanılmıştır. Bu ölçek için belirlenen Cronbach Alpha güvenirlik katsayısı =0,8739 olarak bulunmuştur. 3'lülikert tipinde olan ölçeğin kullanımı için gerekli izin alınmıştır. Bu ölçek, deney ve kontrol grubuna, çalışma öncesi ve sonrasında ön-son test olarak uygulanmış ve öğrencilerin fen bilimlerine yönelik tutumlarında herhangi bir değişiklik olup olmadığı belirlenmiştir.

\section{Veri Toplama İşlemi}

Yapılan çalışma, 2016-2017 eğitim öğretim yılı 7. sınıf öğrencileri ile "maddenin tanecikli yapısı ve karışımlar" konularında gerçekleştirilmiş olup derslerin tamamı araştırmacının bizzat kendisi tarafından yürütülmüştür. Araştırmanın uygulama süreci deney ve kontrol grubunda toplam 3 hafta 10 ders saati ile sinurlı tutulmuştur. Süreç boyunca dersler, kontrol grubunda Millî Eğitim Bakanlığının resmî olarak belirttiği programa ve ders kılavuzlarında gösterildiği şekilde uygulanmıştır. Deney grubunda ise aynı ders programı, probleme dayalı öğrenme yöntemi ile geliştirilmiş $5 \mathrm{E}$ öğre- 
tim modeline dayalı hazırlanan ders planı ve çalışma kâğıtları ile yürütülmüştür. Derinleştirme aşamasında probleme dayalı öğrenme yöntemi verilerek öğrencilerde bilgiyi daha anlamlı hale getirmek ve günlük yaşamla ilişkilendirerek üst düzey öğrenmeler gerçekleştirilmesi amaçlanmıştır. Bu aşamada öğrencilere günlük yaşamda karşılaşabilecekleri az yapılandırılmış problem senaryoları verilerek bu senaryolara çözüm yolları üretmeleri istenmiştir.

Uygulama, 5E öğretim modeline göre hazırlandığında süreç şu şekilde gelişmiştir:

Uygulamayı gerçekleştirebilmek için ilk olarak 5E öğretim modeline uygun ve derinleştirme aşamasında probleme dayalı öğrenme yöntemi olan her ders saatine ait beş tane ders planı hazırlanmıştır. Daha sonra ders işlenişinde öğrencilere dağıtmak için her ders saatine ait beş tane çalışma yaprakları oluşturulmuştur.

5E öğretim modeline göre beş aşamadan oluşan ders planlarının giriş aşamasında öğrencilerin hazırbulunuşluk seviyelerini anlayabilmek için; öğrencinin dikkatini çekecek bir hikâye ya da soru cevaplar verilmiştir. Keşfetme aşamasında bütün ders palanlarında konu ile ilgili deney verilmiştir.

Açılama aşamasına, konunun öğrencilere açılamasının yapılabilmesi için resimli konu anlatımı yazılmıştır. Derinleştirme aşamasında probleme dayalı öğrenme yöntemi kullanılmış ve öğrencilere konu ile ilgili günlük yaşamdan senaryolar yazılmıştır. Senaryolara öğrencilerin çözüm yolları üretebilmeleri için senaryoların altına sorular yazılmıştır. Değerlendirme aşamasında konu ile ilgili çoktan seçmeli soru ve boşluk doldurma gibi sorular yazılarak ders planları tamamlanmıştır. Ders planlarında bulunan etkinlikler öğrencilere dağıtılmak için ayrıca çalışma yaprakları hazırlanmıştır. Hazırlanan çalışma yapraklarından bir örneği aşağıda örneklendirilmiştir.

\begin{tabular}{ll}
\hline Dersin Adi & Fen Bilimleri \\
\hline Sinif & 7. Sinıf \\
\hline Ünite Adi- No & Maddenin Yapısı Ve Özellikleri \\
\hline Konu & Element Ve Bileşik Modelleri \\
\hline Önerilen Süre & 40+40 Dakika \\
\hline Öğrenci & 5.1 Farklı Atomların Bir Araya Gelerek Yeni Maddeler Oluşturabileceğini Fark \\
Kazanimlari & Eder. (Bsb-5) \\
& 5.2 Her Bileşikte En Az Iki Element Bulunduğunu Fark Eder. 5.3 Molekül Yapilı \\
& Bileşiklerin Model Veya Resmi Üzerinde Atomları Ve Molekülleri Gösterir.(Bsb- \\
\hline
\end{tabular}


28)

5.6 Element Ve Bileşiklerin Hangilerinin Moleküllerden Oluştuğuna Örnekler Verir.

\begin{tabular}{ll}
\hline $\begin{array}{l}\text { Fen- Teknoloji- } \\
\text { Toplum- Çevre }\end{array}$ & $\begin{array}{l}\text { Bilimsel Bilginin Açıklanmasında Sunumda Modellerden Yararlanmanın Önemi- } \\
\text { ni Bilir.(Fttç-4, Eğitsel Oyun) }\end{array}$ \\
\hline $\begin{array}{l}\text { Bilimsel Süreç } \\
\text { Becerileri }\end{array}$ & $\begin{array}{l}\text { Bsb-9: Gözlem, Çıkarım Veya Deneylere Dayanarak Geleceğe Yönelik Olası } \\
\text { Sonuçlar Hakkında Fikir Öne Sürer. } \\
\text { Bsb-28: Deney Ve Gözlemlerden Elde Edilen Verileri Derleyip Işleyerek Gözlem } \\
\text { Sıklı̆ı Dağılımı, Çubuk Grafik, Tablo Ve Fiziksel Modeller Gibi Farklı Formlarda } \\
\text { Gösterir. } \\
\text { Bsb-30: İ̧lenen Verileri Ve Oluşturulan Modeli Yorumlar }\end{array}$ \\
& $\begin{array}{l}\text { Td-1: Öğrenmeye Ve Anlamaya Meraklıdır Ve Istek Duyar. } \\
\text { Td-2: Görevleri Isteyerek Gönüllü Olarak Yapar } \\
\text { Td-3: Sorumluluklarını Yerine Getirmeye Gayret Eder. }\end{array}$ \\
& $\begin{array}{l}\text { Probleme Dayalı Öğrenme, Buluş Yoluyla Öğretim Stratejisi, Anlatım Yönte- } \\
\text { Tutum Ve Değerler }\end{array}$ \\
\hline $\begin{array}{l}\text { Öğgretme- } \\
\text { Öğrenme Yöntem -Cevap Tekniği } \\
\text { Ve Teknikleri }\end{array}$ & \\
\hline $\begin{array}{l}\text { Kullanilan } \\
\text { Ĕgitim Teknolojileri- }\end{array}$ & Renkli Oyun Hamurları, Kürdan, Pinpon Topları \\
Araç Ve Gereçler & \\
\hline Kaynakça & 7. Sinıf Ders Kitabı \\
\hline
\end{tabular}

Giriş Öğretmen Öğrencilere Selam Verdikten Sonra "Televizyonda Bir Program Var,

(Engage) Beyaz Show'u Izleyen Var Mi? Bir Zamanlar O Programda Gelen Konuklara Bir Hortuma Üfletilip Ses Değişiyordu. Sizce Bunun Nedeni Nedir? O Hortumun Içinde Ne Vardı Da Ses Değişiyordu?" Diye Sorar. Öğrencilerden Cevap Alındıktan Sonra; “Peki, Temel Reis'i Izlemeyen Var Mı? Temel Reis Ile Kabasakal Arasındaki En Belirgin Fark Nedir? Peki Onun Güçlü Olmasını Sağlayan Nedir? Ispanakta Güç Veren Nedir Peki?" Şeklinde Sorular Sorarak Öğrencilerin Dikkatini Çekmeye Çalışır. Daha Sonrasında, Öğrencilere Konu Ile Ilgili Resimler Gösterilir. Resimler Içerisinde Tuz Ve Tuzu Oluşturan ' $\mathrm{Na}^{\prime}$ Elementi Ile ' $\mathrm{Cl}^{\prime}$ Elementi Yer Alır. Tuzun Üzerinde "Hiçbir Şey Hatırlamıyorum. Ben Kimim? Nasıl Oluştum?" Yazısı Yer Alırken "Na Ve $\mathrm{Cl}^{\prime}$ Atomlarının Üzerinde "Biz Oluşturduk Seni." Yazısı Yer Alır. Bunun Üzerine Tuz:" Nasıl Olur? Ben Size Hiç Benzemiyorum. Hatta Siz De Birbirinize Hiç Benzemiyorsunuz." Der. Aynı Şekilde Su Ve Suyu Oluşturan "H Ve O" Elementlerinin De Resimleri Gösterilir. Gösterilen Bu Resimlerden Yola Çıarak Öğrencilerin Yorum Yapmaları Istenir. Arkadaşlar Bugün Elementler Ve Bileşikleri Öğreneceğiz Diyerek Derse Geçilir.

\begin{tabular}{|c|c|}
\hline $\begin{array}{l}\text { Kescfetme } \\
\text { (Explore) }\end{array}$ & $\begin{array}{l}\text { Öğrencilere Element, Bileşik Ve Molekül Kavramını Anlatılması Ve Aralarındaki } \\
\text { Ilişkinin Anlaşılmasının Sağlanması Için Etkinlik } 1 \text { "Molekül Şekilleri” Deneyi } \\
\text { Yaptırlır. }\end{array}$ \\
\hline $\begin{array}{l}\text { Açiklama } \\
\text { (Explain) }\end{array}$ & $\begin{array}{l}\text { Çok Sayıda Aynı Çeşit Atomların Bir Araya Gelerek Oluşturduğu Maddelere } \\
\text { Element Denir. Elementlerdeki Atomlar Tek Çeşittir Ve Elementler Saf Maddeler- } \\
\text { dir. Molekülü Oluşturan Farklı Çeşitteki Atomların Büyüklükleri Ve Özellikleri } \\
\text { De Birbirinden Farklıdır. Bir Molekül Iki Atomdan Oluştuğu Gibi Çok Fazla } \\
\text { Sayıda Atomdan Da Oluşabilir. Moleküller Az Sayıda Atom Içeriyorsa Basit } \\
\text { Yapılı; Çok Sayıda Atomdan Oluşmuşsa Karmaşık Yapılı Olarak Adlandırılı. En } \\
\text { Az Iki Farklı Elementin Bir Araya Gelerek Oluşturdukları Yeni, Saf Maddelere } \\
\text { Bileşik Denir. Elementler Bileşiği Oluşturmak Için Bir Araya Geldiklerinde Farklı } \\
\text { Özelliklere Sahip Yeni Bir Madde Oluşturur. Bileşik Kendisini Oluşturan Element- }\end{array}$ \\
\hline
\end{tabular}


lerden Tamamen Farklı Özelliklere Sahiptir. Bileşiklerin Çoğu Moleküllerden Oluşmuştur. Bir Bileşiği Oluşturan Moleküllerin Her Biri Diğeriyle Aynı Sayıda Atom Içerir. Bileşiği Oluşturan Moleküllerden Biri Kaç Çeşit Atoma Sahipse Diğer Moleküller De O Kadar Çeşit Atoma Sahiptir. Madde Moleküllerden Oluşmuşsa O Madde Moleküler Yapıda, Atomlardan Oluşmuşsa Madde Atomik Yapıda Bulunur.

Belirli Sayıdaki Farklı Atomlar Birleşerek Atom Kümesi Oluşturduğunda Bu Atom Kümelerinden Oluşan Yapı Moleküler Yapılı Bileşiktir.

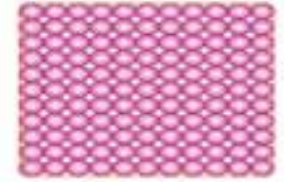

Atom Yapifi Eloment

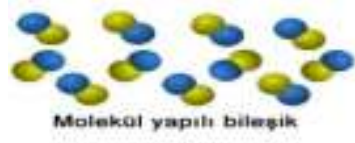

cos 00000

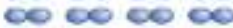

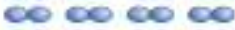

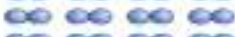

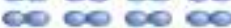

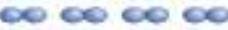

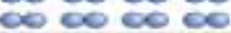

Molekal Vopilt Element

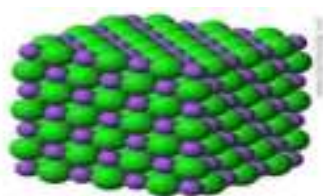

Molekel yapth olmayan bilesik

\section{Derinleştir- Me (Elaborete)}

Probleme Dayalı Öğrenme Yöntemi Kullanılarak Bu Aşama Gerçekleştirilir. Sınıf 6'şar Kişilik Gruplara Ayrılarak 5 Tane Grup Oluşturulur. Daha Sonra Bir Senaryo Örneği Bütün Gruplara Dağıtilır.

Ayşe'nin O Gece Uykusu Çok Gelmişti Ama Israrla Annesinden Ona Hikaye Okumasını Istiyordu. Annesi De Onu Kıramadı Ve Beraber Ayşe'nin Odasına Gittiler. Ayşe Kitaplıktan Bir Hikaye Seçti Ve Annesi Okumaya Başladı." Bir Ülkede Element Ve Bileşik Adında Iki Şehir Varmış. Bu Şehirlerde Yaşayan Insanların Uymaları Gereken Kurallar Varmış. Örneğin Bileşik Şehrinde Yaşamak Istiyorsanız Aile Olmak Zorundasını Yani Kadın Ve Erkek Bir Arada Bulunmalı. Element Şehrinde Ise Durum Biraz Daha Farklı. Element Şehrinin Iki Tane Farklı Ilçesi Varmış. Bunların Adları Ise Atomik Ilçesi Ve Molekül Ilçesiymiş. Atomik Ilçesinde Sadece Erkekler Yaşar Ve Bu Erkekler Bütün Işleri Beraber Yaparlar, Hiç Birbirlerinden Ayrılmazlarmıs. Molekül Ilçesinde Ise Sadece Kızlar Yaşar Fakat Bu Kızların Atomik Ilçesindeki Erkeklerden Biraz Farklı Yaşam Tarzları Varmış. Bir Evde Iki Veya Üç Kişilik Gruplar Halinde Kalırlarmış. Her Grup Diğerlerinden Bağımsız Işler Yapabilirlermiş̧. Ayşe Annesini Durdurdu Ve 'Anneciğim Benim Aklım Karışı Biz Bir Aileyiz Ama Babam Işe Gidince Seninle Ikimiz Evde Kalıyoruz Ve Beraber Iş De Yapıyoruz Biz Şimdi Hangi Şehir Oluyoruz' Diye Sormuştur.

- $\quad$ Ayşe'nin Problemi Nedir Tanımlayınız.

- $\quad$ Siz Annesi Yerinde Olsaydınız Ayşénin Sorduğu Soruya Nasıl Cevap Verirdiniz, Çözüm Önerileri Üretin.

- $\quad$ Sizce Hikaye De Herhangi Bir Yanlışlık Var Mı? Varsa Düzeltiniz.

- $\quad$ Ayşe'nin Problemini Sınıf Arkadaşlarınız lle Birlikte Tartısarak Çözümler Üretiniz.

Tombala Oyunu

Değerlendir-Me Daha Önceden Bir Periyodik Cetvel Çizilir. 18 Elementin Isimleri Periyodik (Evaluate) Cetvelde Yerlerine Yazılır. Yuvarlak Şeklinde Kesilmiş Kartonların Her Iki Tarafı- 
na Da Elementlerin Simgeleri Yazllır. Yuvarlak Kartonlar Küçük Bir Poşetin Içine Atilir.

Etkinlik Sınıfa Hazır Olarak Getirilir. Sınıftaki Öğrenciler Teker Teker Çağırılır Ve Öğrenciden Tombala Poşetinden Bir Tane Kağıt Çekmesi Istenir. Seçtiği Sembolün Hangi Elemente Ait Olduğunu Bulur Ve Sembol Yazılı Kartı Elementin Isminin Yazılı Olduğu Karenin Üzerine Koyar. Bu Her Öğrenci Için Tekrarlanır. Ve Sonunda Periyodik Tablo 18 Element Için Tamamlanmış Olur.

Aşağıda Bazı Semboller Ve Formüller Karışık Olarak Verilmiştir.Aşağıdaki Sembol Kutusuna Sembolleri, Formül Kutusuna Formülleri Yerleştiriniz.

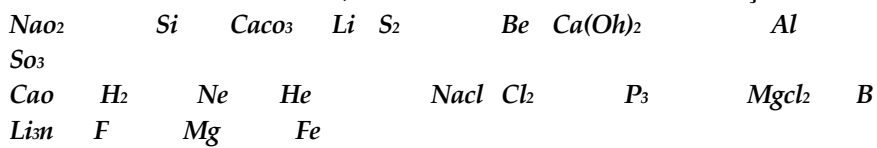

Sembol Kutusu Formül Kutusu

Yukarıdaki gibi hazırlanan ders planları ve çalışma yapraklarının uygulama öncesinde Giresun Özel Bilgi Etüt Eğitim Kurumlarında pilot çalışması gerçekleştirilmiştir. 5E öğretim modeline göre dersler işlenmiş derinleştirme aşamasına gelindiğinde ise probleme dayalı öğrenme yöntemi uygulanmıştır. Bunun için önce öğrenciler eşit sayıda gruplara ayrılmıştır. Daha sonra öğrencilere senaryolar dağıtılarak, senaryodaki probleme çözüm yolları üretmeleri istenmiş ve tartışma ortamı yaratılmıştır. Probleme dayalı öğrenme yöntemi uygulanırken öğrencilerin gayet istekli bir şekilde derse katıldıkları, hem kendi grubundaki hem de diğer gruplardaki arkadaşlarıyla da fikir alışverişleri ve fikir ayrılıklarında bulundukları görülmüştür. Verilen senaryolar günlük yaşamla ilgili olduğu için öğrencilerin daha çok ilgisini çekmiş, sadece probleme dayalı öğrenme yöntemi ilk defa uygulandığı için öğrenciler senaryolar ile ilgili sorulan soruların bazılarında zorlanmışlardır. Bu durum göz önüne alınarak asıl çalışmadan önce zorlanılan sorularda değişiklikler yapılmıştır.

Asıl çalışma Doğankent İmam Hatip Ortaokulunda gerçekleştirilmiştir. Pilot çalışma sonrasında birtakım değişikliklerle geliştirilen ders planları ve çalışma yaprakları uygulanmıştır. Çalışma 10 ders saati, beş tane ders planı 
ve beş tane de çalışma yapraklarıyla gerçekleştirilmiştir. Her ders planına 2 ders saati ayrılmıştır. Çalışmada mevcut fen bilimleri programının derinleştirme aşamasında probleme dayalı öğrenme yöntemi verilmiş ve bunun için derinleştirme aşamasına gelindiğinde sınıf gruplara ayrılmıştır. Her gruba senaryolar dağıtılmış, senaryoları okumaları ve altındaki sorulara çözüm yolları üretmeleri istenmiştir. Her grup üyeleri senaryolara çözüm yoları üretmiş ayrıca grup arkadaşları ile birlikte de ortak çözüm yolları oluşturmuşlardır. Bütün gruplar bu işlemi gerçekleştirdikten sonra gruplar aralarında bir tartışma ortamı oluşturulmuştur. Zaten verilen senaryolar günlük yaşamla ilgili olduğunda öğrencilerin fikir yürütmeleri ve kendi düşüncelerini ortaya koymaları daha kolay olmuştur. Her grup kendi çözüm yollarını söylemiş, kendi düşüncesini savunmuş ve çalışma sonunda gruplar arasında ortak bir düşünceye varılmıştır. Derinleştirme aşamasından sonra değerlendirme aşamasına geçilerek ders planları ve çalışma yaprakları tamamlanmıştır. Bütün bu işlemler sırasında öğretmen ve araştırmacı sadece rehber konumunda olmuş öğrenciler kendi öğrenmelerini gerçekleştirmişlerdir.

\section{Verilerin Analizi}

Yapılan çalışmada deney ve kontrol gruplarına uygulanan başarı testi ve tutum ölçeğinden elde edilen ön - son test verilerinin nicel analizleri için SPSS 16.0 paket programı kullanılmıştır. Çalışma öncesi ve sonrası kontrol ve deney gruplarına ön-son testler uygulanarak ortalama puanları bulunmuş ve bağımsız gruplar t-testi analizleri yapılmıştır.

\section{Bulgular}

\section{Öğrencilerin Akademik Başarı Testi Ön Test Puanlarına İlişkin Bulgular}

Deney ve kontrol gruplarının başarı testi ön test sonuçlarından aldıkları puanlar Tablo 1' de gösterilmiştir. 
Tablo 1. Deney ve Kontrol Gruplarnın Başarı Testi Ön Test Puanlarna İlişkin "Bağımsız Gruplar t Testi" Sonuçlan

\begin{tabular}{|c|c|c|c|c|c|c|c|}
\hline Grup & Ölçüm & $\mathbf{N}$ & $\bar{x}$ & SS & Sd & $t$ & $\mathbf{P}$ \\
\hline Kontrol & \multirow{2}{*}{ Ön test } & 20 & 4.60 & 1.46 & .327 & \multirow[t]{2}{*}{-.906} & \multirow{2}{*}{$.371^{*}$} \\
\hline Deney & & 20 & 5.05 & 1.66 & .373 & & \\
\hline
\end{tabular}

Tablo 1 incelendiğinde; öğrencilerin ön-test başarı testi puanları ortalaması deney grubu için 5.05 kontrol grubu öğrencilerinin ön-test başarı testi puanları ortalaması ise 4.60 çımıştır. Ayrıca deney grubunun standart sapma değeri 1.66, kontrol grubunun standart sapma değeri ise 1.46 olarak bulunmuştur. Deney ve kontrol gruplarındaki öğrencilerin başarı testi ön testten aldıkları puanlar arasında anlamlı bir farklılık olmadığı görülmekte$\operatorname{dir}(\mathrm{p}=.371, \mathrm{p}>.05)$.

\section{Öğrencilerin Akademik Başarı Testi Son Test Puanlarna İlişkin Bulgular}

Deney ve kontrol gruplarının başarı testi son test sonuçlarından aldıkları puanlar aşağıdaki Tablo 2 de gösterilmiştir.

Tablo 2. Deney ve Kontrol Gruplarının Başarn Testi Son Test Puanlarına İlişkin "Bağımsız Gruplar t Testi" Sonuçlarn

\begin{tabular}{|c|c|c|c|c|c|c|c|}
\hline Grup & Ölçüm & $\mathbf{N}$ & $\bar{x}$ & SS & Sd & $t$ & , \\
\hline Kontrol & \multirow{2}{*}{ Son test } & 20 & 10.70 & 1.65 & .370 & \multirow{2}{*}{-6.06} & \multirow{2}{*}{$.000^{\circ}$} \\
\hline Deney & & 20 & 13.45 & 1.19 & .266 & & \\
\hline
\end{tabular}

Tablo 2 incelendiğinde; öğrencilerin son-test, başarı testi puanları ortalaması deney grubu için 13.45, kontrol grubu öğrencilerinin ise son-test başarı testi puanları ortalaması 10.70' tir. Ayrıca deney grubunun standart sapması 1.19, kontrol grubunun standart sapması 1.65 olarak bulunmuştur. Deney ve kontrol gruplarındaki öğrencilerin başarı testi son testten aldıkları puanlar arasında deney grubu lehine anlamlı bir farklılık olduğu görülmektedir $(\mathrm{p}=0.00, \mathrm{p}<.05)$. 


\section{Akademik Başarı Testi Sorularının Ortalama Değerlerine İlişkin Bulgular}

Ön ve son test olarak uygulana akademik başarı testinin ortalama puanlarına ilişkin bulgular aşağıda belirtilmiştir.

Kontrol Grubu Ön Test Ortalama Değerlerine İlişkin Bulgular: Kontrol grubu başarı testi sorularının ön test ortalama değerleri Tablo 3' de verilmiştir.

Tablo 3. Başarn Testi Sorularnnı Kontrol Grubu Ön Test Ortalama Değerlerinin Sonuçlam

\begin{tabular}{llllll}
\hline Sorular & $\mathbf{N}$ & Minimum & Maksimum & $\mathbf{X}$ & SS \\
\hline $\mathbf{1}$ & 20 & 0 & 1 & .65 & .489 \\
\hline $\mathbf{2}$ & 20 & 0 & 1 & .25 & .444 \\
\hline $\mathbf{3}$ & 20 & 0 & 1 & .30 & .470 \\
\hline $\mathbf{4}$ & 20 & 0 & 1 & .30 & .470 \\
\hline $\mathbf{5}$ & 20 & 0 & 1 & .10 & .308 \\
\hline $\mathbf{6}$ & 20 & 0 & 1 & .35 & .489 \\
\hline $\mathbf{7}$ & 20 & 0 & 1 & .10 & .308 \\
\hline $\mathbf{8}$ & 20 & 0 & 1 & .25 & .444 \\
\hline $\mathbf{1 0}$ & 20 & 0 & 1 & .30 & .470 \\
\hline $\mathbf{1 1}$ & 20 & 0 & 1 & .50 & .513 \\
\hline $\mathbf{1 2}$ & 20 & 0 & 1 & .35 & .489 \\
\hline $\mathbf{1 3}$ & 20 & 0 & 1 & .25 & .444 \\
\hline $\mathbf{1 4}$ & 20 & 0 & 1 & .20 & .410 \\
\hline $\mathbf{1 5}$ & 20 & 0 & 1 & .40 & .503 \\
\hline Toplam & 20 & 0 & 1 & .30 & .470 \\
\hline & 20 & 2 & 7 & 4.60 & 1.465 \\
\hline
\end{tabular}

Tablo 3 incelendiğinde; başarı testi kontrol grubu ön test ortalama değerleri her soru için farklı sonuçlar vermektedir. 20 sorudan minimum 2, maksimum ise 7 aldıkları görülmektedir. Ortalama değerlerinde en yüksek .65 ile 1. Sorunun olduğu; en düşük ise .10 ile birlikte 5 . Ve 7. Soruların olduğu tespit edilmiştir. Soruların ortalama toplam değerine bakıldığında ise, 4.60 bulunmuştur.

Kontrol Grubu Son Test Ortalama Değerlerine İlişkin Bulgular: Kontrol grubu başarı testi sorularının son test ortalama değerleri Tablo 4 ' de verilmiştir.

Tablo 4 incelendiğinde; başarı testi kontrol grubu son test ortalama değerleri her soru için farklı sonuçlar vermektedir. 20 sorudan minimum 7 maksimum ise 14 aldıkları görülmektedir. Ortalama değerlerinde en yüksek 
.85 ile 2. sorunun olduğu; en düşük ise .40 ile 5 . sorunun olduğu tespit edilmiştir. Soruların ortalama toplam değerine bakıldığında ise, 10.65 bulunmuştur.

Tablo 4. Başarn Testi Sorularnmı Kontrol Grubu Son Test Ortalama Değerlerinin Sonuçlam

\begin{tabular}{llllll}
\hline Sorular & $\mathbf{N}$ & Minimum & Maksimum & $\mathbf{X}$ & SS \\
\hline $\mathbf{1}$ & 20 & 0 & 1 & .70 & .470 \\
\hline $\mathbf{2}$ & 20 & 0 & 1 & .85 & .366 \\
\hline $\mathbf{3}$ & 20 & 0 & 1 & .50 & .513 \\
\hline $\mathbf{4}$ & 20 & 0 & 1 & .75 & .444 \\
\hline $\mathbf{5}$ & 20 & 0 & 1 & .40 & .503 \\
\hline $\mathbf{6}$ & 20 & 0 & 1 & .80 & .410 \\
\hline $\mathbf{7}$ & 20 & 0 & 1 & .60 & .503 \\
\hline $\mathbf{8}$ & 20 & 0 & 1 & .70 & .470 \\
\hline $\mathbf{9}$ & 20 & 0 & 1 & .80 & .419 \\
\hline $\mathbf{1 0}$ & 20 & 0 & 1 & .80 & .410 \\
\hline $\mathbf{1 1}$ & 20 & 0 & 1 & .70 & .470 \\
\hline $\mathbf{1 2}$ & 20 & 0 & 1 & .80 & .410 \\
\hline $\mathbf{1 3}$ & 20 & 0 & 1 & .80 & .410 \\
\hline $\mathbf{1 4}$ & 20 & 0 & 1 & .70 & .470 \\
\hline $\mathbf{1 5}$ & 20 & 0 & 1 & .80 & 1.599 \\
\hline Toplam & 20 & 7 & 14 & 10.65 & \\
\hline & & & & & \\
\hline
\end{tabular}

Deney Grubu Ön Test Ortalama Değerlerine İlişkin Bulgular: Deney grubu başarı testi sorularının ön test ortalama değerleri Tablo 5' de verilmiştir.

Tablo 5. Başarn Testi Sorularının Deney Grubu Ön Test Ortalama Değerlerinin Sonuçları

\begin{tabular}{llllll}
\hline Sorular & $\mathbf{N}$ & Minimum & Maksimum & $\mathbf{X}$ & SS \\
\hline $\mathbf{1}$ & 20 & 0 & 1 & .70 & .470 \\
\hline $\mathbf{2}$ & 20 & 0 & 1 & .50 & .513 \\
\hline $\mathbf{4}$ & 20 & 0 & 1 & .55 & .510 \\
\hline $\mathbf{5}$ & 20 & 0 & 1 & .25 & .444 \\
\hline $\mathbf{6}$ & 20 & 0 & 1 & .20 & .410 \\
\hline $\mathbf{7}$ & 20 & 0 & 1 & .20 & .410 \\
\hline $\mathbf{8}$ & 20 & 0 & 1 & .25 & .444 \\
\hline $\mathbf{9}$ & 20 & 0 & 1 & .30 & .470 \\
\hline $\mathbf{1 0}$ & 20 & 0 & 1 & .25 & .444 \\
\hline $\mathbf{1 1}$ & 20 & 0 & 1 & .30 & .470 \\
\hline $\mathbf{1 2}$ & 20 & 0 & 1 & .35 & .489 \\
\hline $\mathbf{1 3}$ & 20 & 0 & 1 & .25 & .444 \\
\hline $\mathbf{1 4}$ & 20 & 0 & 1 & .35 & .489 \\
\hline $\mathbf{1 5}$ & 20 & 0 & 1 & .30 & .470 \\
\hline Toplam & 20 & 0 & 1 & .30 & .470 \\
\hline & 20 & 3 & 8 & 5.05 & 1.669 \\
\hline
\end{tabular}


Tablo 5 incelendiğinde; başarı testi deney grubu ön test ortalama değerleri her soru için farklı sonuçlar vermektedir. 20 sorudan minimum 3, maksimum ise 8 aldıkları görülmektedir. Ortalama değerlerinde en yüksek .70 ile 1 . Sorunun olduğu; en düşük ise 20 ile 5 . ve 6 . Soruların olduğu tespit edilmiştir. Soruların ortalama toplam değerine bakıldığında ise, 5.05 bulunmuştur.

Deney Grubu Son Test Ortalama Değerlerine İlişkin Bulgular: Deney grubu başarı testi sorularının son test ortalama değerleri Tablo $6^{\prime}$ da verilmiştir.

Tablo 6. Başan Testi Sorularmın Deney Grubu Son Test Ortalama Değerlerinin Sonuçla-

\begin{tabular}{llllll}
$\boldsymbol{n}$ & $\mathbf{N}$ & Minimum & Maksimum & $\mathbf{X}$ & SS \\
\hline Sorular & $\mathbf{N}$ & 0 & 1 & .95 & .224 \\
\hline $\mathbf{2}$ & 20 & 0 & 1 & 1.00 & .000 \\
\hline $\mathbf{3}$ & 20 & 0 & 1 & .90 & .308 \\
\hline $\mathbf{4}$ & 20 & 0 & 1 & 1.00 & .000 \\
\hline $\mathbf{5}$ & 20 & 0 & 1 & .75 & .444 \\
\hline $\mathbf{6}$ & 20 & 0 & 1 & .80 & .410 \\
\hline $\mathbf{7}$ & 20 & 0 & 1 & .90 & .308 \\
\hline $\mathbf{8}$ & 20 & 0 & 1 & .95 & .224 \\
\hline $\mathbf{9}$ & 20 & 0 & 1 & .90 & .308 \\
\hline $\mathbf{1 0}$ & 20 & 0 & 1 & .95 & .224 \\
\hline $\mathbf{1 1}$ & 20 & 0 & 1 & .90 & .410 \\
\hline $\mathbf{1 2}$ & 20 & 0 & 1 & .95 & .444 \\
\hline $\mathbf{1 3}$ & 20 & 0 & 1 & 1.00 & .000 \\
\hline $\mathbf{1 4}$ & 20 & 0 & 1 & .85 & .224 \\
\hline $\mathbf{1 5}$ & 20 & 0 & 1 & .95 & 1.191 \\
\hline Toplam & 20 & 12 & 15 & 13.45 & \\
\hline & & & & & \\
\hline
\end{tabular}

Tablo 6 incelendiğinde; başarı testi deney grubu son test ortalama değerleri her soru için farklı sonuçlar vermektedir. 20 sorudan minimum 12, maksimum ise 15 aldıkları görülmektedir. Ortalama değerlerinde en yüksek 1.00 ile 2,4 ve 13 . Soruların olduğu; en düşük ise .75 ile 5 . Ve 12 . Soruların olduğu tespit edilmiştir. Soruların ortalama toplam değerine bakıldığında ise, 13.45 bulunmuştur.

\section{Öğrencilerin Fen Bilimleri Tutum Ölçeği Test Puanlarnna İlişkin Bulgular}

Bu bölümde deney ve kontrol gruplarının Fen Bilimleri Tutum Ölçeği önson test sonuçlarından aldıkları puanlara ilişkin bulgular verilmiştir. 
Fen bilimleri Tutum Ölçeği Ön-Test Puanlarnna ilişkin Bulgular: Deney ve kontrol gruplarına uygulanan Fen Bilimleri Tutum Ölçeği ön test puanlar1na ilişkin analiz sonuçları Tablo 7 de verilmiştir.

Tablo 7. Deney ve Kontrol Gruplarının Fen Bilimleri Tutum Ölçeği Ön-test Puanlarına İlişkin "Bağımsız Gruplart Testi" Sonuçları

\begin{tabular}{|c|c|c|c|c|c|c|c|}
\hline Grup & Ölçüm & $\mathbf{N}$ & $\bar{x}$ & SS & Sd & $\mathrm{T}$ & $\mathbf{P}$ \\
\hline Kontrol & \multirow{2}{*}{ Ön test } & 20 & 28.55 & 4.22 & .944 & \multirow[t]{2}{*}{-1.822} & \multirow{2}{*}{$.076^{*}$} \\
\hline Deney & & 20 & 30.55 & 2.50 & .559 & & \\
\hline
\end{tabular}

Tablo 7 incelendiğinde; öğrencilerin ön-test başarı testi puanları ortalaması deney grubu için 30.55 , kontrol grubu öğrencilerinin ise son-test başarı testi puanları ortalaması 28.55 çıkmıştır. Grupların standart sapma değerleri ise; deney grubunun standart sapmas1 2.50, kontrol grubunun standart sapmasi 4.22 olarak bulunmuştur. Deney ve kontrol gruplarındaki öğrencilerin başarı testi ön testten aldıkları puanlar arasında anlamlı bir farklılık olmadığı görülmektedir ( $\mathrm{p}=.076, \mathrm{p}>.05)$.

Fen Bilimleri Tutum Ölçeği Son Test Puanlarna İlişkin Bulgular: Bu bölümde deney ve kontrol gruplarına uygulanan Fen Bilimleri Tutum Ölçeği son test analizleri Tablo 8 de verilmiştir.

Tablo 8. Deney ve Kontrol Gruplarnnn Tutum Ölçeği Son-test Puanlarnna İlişkin "Bağımsız Gruplart Testi" Sonuçlan

\begin{tabular}{|c|c|c|c|c|c|c|c|}
\hline Grup & Ölçüm & $\mathbf{N}$ & $x$ & SS & Sd & $T$ & $p$ \\
\hline Kontrol & \multirow{2}{*}{ Son test } & 20 & 28.85 & 2.71 & .608 & -6.637 & \multirow{2}{*}{$.000^{*}$} \\
\hline Deney & & 20 & 33.00 & .648 & .145 & & \\
\hline
\end{tabular}

Tablo 8 incelendiğinde; öğrencilerin son-test başarı testi puanları ortalaması deney grubu için 33.00, kontrol grubu öğrencilerinin ise son-test başarı testi puanları ortalaması 28.85 olarak bulunmuştur. Deney grubunun standart sapması .648 kontrol grubunun standart sapması 2.71 olarak tespit edilmiştir. Deney ve kontrol gruplarındaki öğrencilerin başarı testi son testten aldıkları puanlar arasında anlamlı bir farklılık olduğu görülmektedir ( $\mathrm{p}=0.00$, $\mathrm{p}<.05)$. 


\section{Tartışma, Sonuç ve Öneriler}

Fen Bilimleri derslerinde probleme dayalı öğrenme yönteminin kullanılmasının öğrenci başarına ve öğrencilerin fen derslerine karşı tutumlarına etkisinin incelendiği araştırmanın bu bölümünde; verilen analizleri sonucu elde edilen bulgulara dayanarak sonuç ve tartışma kısmına yer verilmiştir.

\section{Başan Testi Puanlarına İlişkin Tartışma ve Sonuç}

Araştırmada öncelikli olarak çalışma başlamadan önce 7. sınıfta öğrenim gören öğrencilerden hem deney hem de kontrol gruplarına ön test olarak akademik başarı testi uygulanmıştır. Buradaki amaç her iki gruptaki öğrencilerdeki ön bilgileri tespit etmek, çalışma bittikten sonra uygulanacak olana son test ile birlikte çalışmanın verimli olup olmadığını ortaya çıkarmaktır. Ön test sonucunda elde edilen bulgulara bakıldığında; $\mathrm{p}$ değeri $=.371$ çı kmış ve bu değer.05 den büyük olduğu için deney grubu ile kontrol grubu arasında anlamlı bir farklılık olmadığı görülmüştür. Deney ve kontrol gruplarının ön test değerleri arasında anlamlı bir farklılık çıkmaması, probleme dayalı öğrenme yönteminin öğrencilerin akademik başarısına etkisini ortaya koymada daha güvenilir sonuçlar elde edilmesine fayda sağlayacağı düşünülmüştür.

Araştırmanin son test sonucundan elde edilen bulgular incelendiğinde ise; $\mathrm{p}$ değeri= 0.00 çıkmış ve bu değer .05 den küçük olduğu için probleme dayalı öğrenme yöntemi uygulanan deney grubu ile mevcut fen bilimleri dersi öğretim programının uygulandığı kontrol grubu arasında anlamlı bir farklılık ortaya çımıştır. Bu farklılığın da probleme dayalı ögrenme yönteminin uygulandığ Bu sonuca dayanarak probleme dayalı öğrenme yönteminin uygulandığ deneysel çalışmanın yapıldığı grup da, öğrencilerin mevcut fen bilimleri programı uygulanan kontrol grubundaki öğrencilere göre "maddenin tanecikli yapısı ve karışımlar' konularında daha başarılı oldukları sonucu elde edilmiştir. Buradaki başarıyı sağlayan temel etken deney grubuna uygulanan probleme dayalı öğrenme yöntemidir. Probleme dayalı öğrenme yöntemi ile birlikte öğrencilere günlük yaşamla ilgili senaryolar verilmiş; bu senaryolar sayesinde de öğrenciyi derse çekmiş ve öğrencinin derse aktif olarak katıldığı gözlenmiştir. Aidoo, Boateng, Kissi, \& Ofori (2016) ve Ar- 
gaw, Haile, Ayalew, ve Kuma (2016) yapmış oldukları çalışmalarda probleme dayalı öğrenme yönteminin, öğrencilerde problem çözme becerilerini geliştirdiğini tespit etmişlerdir. Kumbasar (2019) yaptığı çalışmada probleme dayalı öğrenme yöntemi ile tasarlanan öğretim materyallerinin öğrencilerin öğrenmelerine katkı sağladığı sonucunu elde etmiştir. Çelik (2010) da yaptığı çalışmada deney grubuna probleme dayalı öğrenme yöntemi, kontrol grubuna geleneksel yöntem uygulamış ve deney grubu tarafina olumlu yönde anlamlı bir farklılık tespit etmiştir. Arslan Turan (2014), İnel (2009), Bayram (2010), Gürlen (2011), Yıldız (2010) ve Aka (2012) yaptıkları çalışmalarında deney grubuna probleme dayalı öğrenme yöntemi uygulamışlar ve deney grubu lehine anlamlı bir farklılık olduğunu tespit etmişlerdir. Savaş (2018) yaptığı çalışmada probleme dayalı öğrenme uygulamalarının kullanıldığ1 7. Sınıf öğrencileri ile deney grubu oluşturmuş, karma yöntemlerin uygulandığı 7. Sınıf öğrencileri ile de kontrol grubu oluşturarak öğrencilerin akademik başarıları arasında deney grubu lehine anlamlı bir farklılık tespit etmiştir. Çoban (2018) yaptığı çalışmada probleme dayalı öğrenme yöntemi ile geleneksel yöntemi karşılaştırmıştır. Çalışmasının sonucunda probleme dayalı ögrenme yönteminin uygulandığı grup lehine anlamlı bir farklılık olduğu gözlemlenmiştir. Ferreira \& Trudel (2012) ve Wong \& Day (2009) de yapmış oldukları çalışmalarda probleme dayalı öğrenme yöntemini fen bilimleri dersinde kullanmış olup bu yöntem ile öğrencilerin derse olan katılımlarının daha fazla olduğunu tespit etmişlerdir.Bir başka çalışma olan Hande, Mohammed, \& Komattil (2015) yapmış oldukları çalışma ile probleme dayalı öğrenme yönteminin öğrencilere bilgi, beceri kazandırılmasında aktif rol oynadığını ayrıca öğrencilerin derse olan ilgilerinin arttığını gözlemlemişlerdir. Bunun yanında probleme dayalı öğrenme yöntemi uygulanan deney grubu ile geleneksel yöntemin uygulandığı kontrol grubu arasında anlamlı bir fark çıkmayan çalışmalarda mevcuttur. Şeker (2015) deney grubuna probleme dayalı ögrenme yöntemi, kontrol grubuna geleneksel yöntem uygulamış; Arslan (2009) ise deney grubuna probleme dayalı öğrenme yöntemi, kontrol grubuna 5E öğretim modeli uygulamış ve her iki çalışmada da deney grubu lehine anlamlı bir farklılık elde edilememiştir.

Bulgular sonucunda elde edilen ortalama değerlere baktığımızda; kontrol grubunun ön test ortalama değeri 4.60 iken son test ortalama değeri 10.70 çıkmıştır. Bu sonuca göre mevcut fen bilimleri programı uygulanan kontrol grubunda uygulama sonrası sınıf başarısında artış meydana gelmiş- 
tir. Deney grubundaki ortalama değerlere bakıldığında ise; ön test ortalama değer sonucu 5.05, son test ortalama değer sonucu 13.45 olarak bulunmuştur. Probleme dayalı öğrenme yönteminin uygulandığı deney grubunda uygulama sonrası ortalama değerlerinde artış gözlenmiştir.

\section{Başan Testinde Yer Alan Günlük Yaşamla İlgili Sorulara Yönelik Tartışma} ve Sonuç: Başarı testi sorularının ortalama değerleri analizleri incelendiğinde; uygulama öncesi gerçekleşen ön test ile uygulama sonrası yapılan son test sorularının ortalama değerleri arasında farklılıklar tespit edilmiştir. Deney grubunda probleme dayalı ögrenme, kontrol grubunda mevcut fen bilimleri programı uygulanmış olsa da iki grubun da son test sorularından elde edilen puanların ortalama değerleri yüksek çıkmıştır. Ancak deney grubunda ki son test sorularını ortalama değerlerinde ki artış daha fazla gözlenmektedir. Probleme dayalı öğrenme verilen günlük yaşamla ilgili senaryolar ile birlikte öğrenciyi problemin merkezine çekmiş ve anlamlı öğrenmeyi sağladığı düşünülmektedir. Bu bağlamda başarı testinde verilen 4, 11, 12 ve 13. sorular günlük yaşamda karşılaşabileceğimiz doğrudan ilgili sorulardır.

Bu soruların deney grubu için ortalama analizlerine bakıldığında ön test ortalamaları; $.25, .35, .25$ ve .35 olduğu; soruların son test ortalama değerlerine bakıldığında ise; 1.00, .90, .95 ve 1.00 sonuçları tespit edilmiştir. Aynı sorularda kontrol grubu için bakıldığında ön test sonuçları, .30, .35, .25ve .20 soruların son test ortalama analizleri, $.75, .70, .80$ ve .80 olduğu görülmektedir. Başarı testi 4, 11, 12 ve 13. soruların deney ve kontrol grupları ortalama değerleri incelendiğinde; probleme dayalı öğrenme yönteminin uygulandığı deney grubunda ortalama değerlerdeki artışın daha fazla olduğu görülmektedir. İncelenen bu sorular günlük yaşamla ilgili sorulardır. Deney grubunda probleme dayalı öğrenme yöntemi uygulanması sonucunda böyle yüksek ortalama değerlerinin çıkması probleme dayalı öğrenme yöntemi ile verilen günlük yaşam senaryolarının istenilen işlevi yerine getirdiği ve öğrencinin başarılı olmasında da daha çok etkili olduğu düşünülmektedir.

Deney grubundaki bazı öğrencilerin, başarı testinde bulunan günlük yaşamla ilgili sorulara verdikleri yantlar ön test ve son test olarak incelenip örneklendirildiğinde; Ö2, Ö8 ve Ö13. Öğrencilerin ön testte bu soruları yanlış yanıt verdikleri; son testte ise doğru yanıtladıkları tespit edilmiştir. Öğrencilerin uygulamadan önce bu soruları günlük yaşamla ilişkilendirmekte 
güçlük yaşadıkları için yanlış cevap verdikleri düşünülmektedir. Fakat uygulama sonrasında aynı öğrencilerin günlük yaşamla ilgili soruları doğru yanıtlaması; öğrencilerin probleme dayalı öğrenme yöntemi sayesinde konuyu günlük yaşamla ilişkilendirerek anlamlandırdıkları düşünülebilir.

\section{Fen Bilimleri Tutum Ölçeğine İlişkin Tartışma ve Sonuç}

Araştırmada 7. Sınıf öğrencilerin fen bilimleri dersine karşı tutumlarını ölçmek için, çalışma başlamadan önce deney ve kontrol gruplarına ön test tutum ölçeği uygulanmıştır. Bu test sonucunda elde dilen bulgular incelendiğinde; $\mathrm{p}$ değeri $=.076$ çıkmıştır. Bu p değeri .05 den büyük olduğu için deney grubu ile kontrol grubu arasında anlamlı bir farklılık görülmemektedir.

Araştırmanın bulguları sonucu elde edilen son test tutum ölçeği verilerine bakıldığında ise $\mathrm{p}$ değeri $=.00$ çıkmış ve bu değer .05 den küçük olduğu için probleme dayalı öğrenme yönteminin uygulandığı deney grubu ile kontrol grubu tutum değerleri arasında deney grubu lehine anlamlı bir farklılık olduğu tespit edilmiştir. Buradan da anlaşılacağı üzere probleme dayalı öğrenme yöntemi öğrencilerin fen bilimlerine karşı tutumların olumlu bir şekilde etkilemiştir. Deney grubundaki öğrenciler probleme dayalı öğrenme yöntemi sayesinde derslerde aktif olarak rol almış bu sayede sıkılmadan gruplar oluşturarak daha verimli dersler geçirilmesi sağlanmış olabilir. Öğrenci bu sayede fen dersini yapamayacağı korkusundan kurtulup aksine kendini senaryolar ile birlikte problemin merkezinde bulmuş olabilir. Ders daha eğlenceli ve verimli geçtiğinden konu daha iyi kavranmış ve anlamlı öğrenmeler gerçekleşmiş olabilir ki bu sonucu bulgulara bakarak da elde edebiliyoruz. Bütün bu sebeplerden dolayı probleme dayalı öğrenme yönteminin uygulandığı deney grubunda olumlu davranışlar kazandırıldığından öğrencilerin fen bilimlerine karşı tutumlarında olumlu değişiklikler meydana gelmiştir. Çelik (2010) çalışmasında Fen'e karşı tutumlarında deney grubu lehine anlamlı bir farklılık görülmüştür. Aynı şekilde Bayraktar (2010), Demirel ve Arslan Turan (2010), yaptıkları çalışmalarda deney grubu lehine anlamlı bir farlılık elde etmişlerdir. Seyhan (2019) yaptığ çalışmada, probleme dayalı öğrenme yöntemiyle işlenen fen bilimleri derslerine karşı öğrencilerin daha olumlu tutum sergilediklerini tespit etmiştir.

Deney ve kontrol gruplarının ortalama değerleri incelendiğinde; deney grubunun ön test ortalama değeri 5.05, kontrol grubunun ortalama değeri 
13.45; kontrol grubunun ön test ortalama değeri 4.60 kontrol grubunun son test ortalama değeri 10.70 olarak elde edilmiştir. Bu bulgulara baktığımızda deney ve kontrol gruplarının ön test ortalama değerlerine göre son test ortalama değerlerinde bir artı̧ gözlenmektedir. Buradan da mevcut fen bilimleri programı uygulanan kontrol grubu ile probleme dayalı öğrenme yöntemi uygulanan deney grubunda gerçekleşen öğretim etkinlikleri verimli olmuştur. Fakat probleme dayalı öğrenme etkinliklerinin uygulandığı deney grubunda ortalama değerlerde daha fazla artış olduğu gözlenmiştir.

\section{Öneriler}

1. Bu çalışmada kullanılan maddenin tanecikli yapısı ve karışımlar konusu soyut bir konudur. Bu soyut konudaki eksik bilgilerin giderilmesinde probleme dayalı öğrenme yöntemi etili olmuş ve bu yöntem fen bilimleri dersi kapsamında başka soyut konularda ya da diğer sınıflarda da uygulanarak faydalanılabilir.

2. Probleme dayalı öğrenme yönteminde seçilen senaryoların önemi ve ders ile ilgili bağlantısı öğrenciye önceden aktarılmalıdır. Ayrıca senaryolar yazılırken öğrencinin içinde bulunduğu yaş dönemi önemsenmeli, onun anlamasını kolaylaştıracak şekilde olmalı ve ders de verilmesi gereken kazanımları kapsamalıdır.

3. Probleme dayalı öğrenme yöntemi diğer yöntem ve tekniklerle birlikte zenginleştirilerek öğretimdeki kalıcılığı artırılabilir.

4. Probleme dayalı öğrenme yöntemi daha az mevcutlu sınıflarda uygulandığında daha iyi sonuçlar elde edilebilir.

5. Probleme dayalı öğrenme yöntemini biz 7. Sınıflarda uyguladık. Bu yöntem 5. ve 6. Sınıf düzeyinde de uygulanarak öğrencilerin fen dersine karşı olumlu davranışlarda bulunmaları sağlanabilir.

6. Probleme dayalı öğrenme yöntemi; soyut konuların pekiştirilmesinde faydalı olduğundan 6. Sınıf müfredatında yer alan 'Madde ve Isı' ünitesinin daha iyi kavranabilmesinde probleme dayalı öğrenme yöntemi uygulanabilir.

7. Çalışmamızda probleme dayalı öğrenme yöntemini 5E modelinin derinleştirme aşamasında uyguladık. Bu yöntem öğrencilere bir problem cümlesi üzerinden verilip keşfetme aşamasında deney ile pekiştirilebilir. 
8. Uygulanan çalışmamız 5E öğretim modeli ile tasarlanmıştır. Onun yerine diğer kuram ve öğretim modelleri ile desteklenen öğretim ortamları hazırlanan farklı çalışmaların da yapılabileceği önerilebilir.

9. Çalışmamızda PDÖ yönteminin, öğrencilerimizin başarılarını arttırdığı ve tutumlarını olumlu yönde geliştirdiği tespit edilmiştir. Özellikle yapılan bu çalışma ile gözlemlerimiz ve test sonuçları ile öğrencilerin inceleme-araştırma-sorgulama gibi düşünsel becerilerinin de harekete geçtiği görülmüştür. Bu anlamda bu tür çalışmaların, özellikle fen liseleri ve mesleki eğitimlerde yapılması da fen ve teknoloji açısından ayrıca önemli görülmektedir. Bakanlığımızdan buna yönelik desteklerin gerçekleştirilmesi önerilebilir.

10. Milli Eğitim Bakanlığımız, probleme dayalı öğrenme yöntemi gibi bu kapsamda kullanılabilecek diğer kuram-model-strateji-yöntem ve teknikleri içeren farklı uygulamalara yönelik hizmet içi eğitim seminerleri gerçekleştirilmesi ve böylece daha çok öğretmene farklı boyutlarda katkı sağlaması önerilebilir. 


\section{EXTENDED ABSTRACT}

\section{Effect Of 5E Teaching Model Supported By Problem-Based Learning On The Achievement And Attitude

\author{
Şerif Ali Değirmençay - Figen Hun \\ Giresun Üniversitesi Ë̆itim Fakültesi-Kazanbey Ortaokulu
} \\ *}

The population in the world is growing rapidly, consumption is accelerating day by day and, accordingly, new technological developments are required to meet human needs and keep up with the times (Çepni \& Çoruhlu, 2009). Here, role of the education becomes more prominent. Education is what individuals essentially need to keep up with the requirements of the time, the technology and the world that constantly evolve and change (Çelik, 2010).

In order to realize all these developments, it is necessary to apply appropriate teaching strategies, methods and techniques for each course as stated in the education-training curriculums. (Dilşeker, 2008). 5E teaching model is one of the models proposed by the education - training curriculum for use in the classroom (Yaman \& Yalçın, 2005). This model is identical to the constructivist learning approach and plays an active role in provision of learning as requested by MoNE. Also, 5E teaching model enables different methods and techniques to be realized in the classroom (Değirmençay, 2010).

One of the different methods and techniques used in the education - training environment is the problem-based learning method (Çınar \& İlik, 2013). With regards to the problem-based learning method, it is ensured that the student faces the problem and the student is asked to generate ways of solution along with scenarios provided to the student. Scenarios provided are connected with the daily life and it is intended to ensure that the child puts herself/himself in the center of the problem and does meaningful learning and associate what she/he learns with the daily life (Gökmen, 2008).

By taking these discoveries as the starting point, will teaching the subjects of granular structure of the mater and mixtures with $5 \mathrm{E}$ teaching model supported by problem-based learning method have an impact upon the academic achievement of students? Will students' attitude towards life sciences change 
as a result of lessons taught with this method? These two questions constitute our case of problem.

The research was conducted on 40 students, including experiment group $=20$ and control group $=20$, at the $7^{\text {th }}$ grade of Dogankent Theological Vocational High School, in the province of Giresun, district of Dogankent, in the academic year of 2016-2017.

Purpose of this study is to detect academic achievement of students and their attitude towards life sciences at the $7^{\text {th }}$ grade life sciences class in the primary school, with 5E teaching model supported by the problem based learning method. In this context, semi experimental method with pretest - posttest content with a control group and experiment group was used in the study conducted. Experimental and control groups are determined by random method in this study. Throughout the study, the study conducted with the control group was conducted by remaining loyal to curriculums specified in life sciences program, whereas curriculums supported by problem-based learning were used in the experiment group. Achievement test and life sciences attitude scale were applied to the experimental and control groups before the process. At the end of the process, the same application was carried out and it was ascertained with statistical data if the problem-based learning method had an impact upon students' academic achievement and their attitude towards life sciences.

A 15-question success test, as developed by Şahin (2016) was used in the research, the validity and reliability of which was calculated. Pretest and posttests derived from the achievement test applied to the experiment and control groups were analyzed with SPSS 16.0 program in this study. Likewise, pretests and posttests derived form the attitude scale applied to the experiment group and control group were analyzed in SPSS 16.0 program and results were recorded.

Data of the achievement test applied to the experiment group and the control group as pretest-posttest were analyzed with independent groups $t$ test, and, further, it was checked if there was a significant difference between pretest and posttest points. Findings related to the attitude scale: data of the attitude scale applied to the experiment group and the control group as pretestposttest were analyzed with independent groups $t$ test, and, further, it was checked if there was a significant difference between pretest and posttest points. 
First of all, before the study was initiated, pretest achievement test was applied to $7^{\text {th }}$ grade students, from both experiment group and control groups, The purpose here was to detect knowledge possessed by students from both groups, and to reveal if the study was efficient along with the posttest to be applied when the study is completed. When looking into findings derived from achievement test pretest; since $\mathrm{p}$ value was found to $\mathrm{be}=.371$ and such value is in excess of .05 , it was ascertained that there was no significant difference between the experiment group and control group. The fact that there was no significant difference between pretest values of the experiment and control groups gives the impression that problem-based learning method will help reveal more significant results in terms of showing its effect on academic achievement of students. When looking into findings derived from the posttest result of the research; since $p$ value was found to $b e=0.00$ and such value is lower than .05 , there was a significant difference between the experiment group to whom the problem-based learning method was applied and the control group to whom the existing life sciences curriculum was applied. Such difference seems to be a difference in favor of the experiment group to whom the problem-based learning method was applied.

In order to measure attitudes of $7^{\text {th }}$ grade students towards the life sciences, a pretest attitude scale was applied to control and experiment groups before the study was initiated. When looking into findings derived as a result of such test, $\mathrm{p}$ value was found to be $=.076$. Since $\mathrm{p}$ value was larger than .05 , there seems to be no significant difference between the experiment group and control group. When looking into posttest attitude scale data derived from findings of the research, since $p$ value was found to be $=.00$ and such value is lower than .05 , it was ascertained that there was a significant difference in favor of the experiment group between the experiment group to whom the problem-based learning method was applied and attitude values of the control group.

\section{Kaynakça / References}

Aidoo, B., Boateng, S. K., Kissi, P. S., ve Ofori, I. (2016). Effect of problem-based learning on students' achievement in chemistry.Journal of EducationPractice, 7(33), 103-108. 
Argaw, A. S., Haile, B. B., Ayalew, B. T., ve Kuma, S. G. (2016). The effect of problem based learning (PBL) instruction on students' motivation and problem solving skills of physics. Eurasia Journal of Mathematics, Science

Bayram, A. (2010). Probleme dayalı öğrenme yönteminin ilköğretim 5. sinı öğrencilerinin fen ve teknoloji dersi isl ve sicaklk konusunda sahip oldukları kavram yanılgıların gidermede etkisi. Selçuk Üniversitesi Eğitim Bilimleri Enstitüsü,

Benli, Özdemir, ve Arık, S. (2017). 2005 Ylı Fen ve Teknoloji Dersi ve 2013 yılı fen bilimleri dersi öğretim programlarınn öğretmen değerlendirmesi. Journal of Kirsehir Education Faculty, 18(1).

Cotič, M.,veZuljan, M. V. (2009). Problem-basedinstruction in mathematicsanditsimpactonthecognitiveresults of thestudentsand on affective-motivationalaspects. Educationalstudies, 35(3), 297-310.

Çelik, E. (2010). Fen eğitiminde probleme dayalı öğrenme yaklaşımının öğrencilerin akademik başarısina, tutumuna, akademik risk alma düzeyine ve kalıcllğg etkisi. Gazi Üniversitesi, Eğitim Bilimleri Enstitüsü,

Çınar, D. (2007). İlköğretim fen eğitiminde probleme dayalı öğrenme yaklaşımının üst düzey düşünme becerilerine ve akademik risk alma düzeyine etkisi. Ĕ̆itim Bilimleri Araştırmalan Dergisi, 3, 22-34.

Çoban, A. (2018). Probleme dayal ö̆gretim (PDÖ) yönteminin kuantum fiziği 'klasik fiziğin yetersizlikleri' konusunun öğretimi üzerine etkilerinin araştırlması. Dokuz Eylül Üniversitesi, Eğitim Bilimleri Enstitüsü, Yüksek Lisans Tezi, İzmir. 152.

Çoruhlu, T. Ş., Nas, S. E., ve Çepni, S. (2009). Fen ve teknoloji öğretmenlerinin alternatif ölçme-değerlendirme tekniklerini kullanmada karşılaştıkları problemler: Trabzon örneği. Yüzüncü Yıl Üniversitesi Eğitim Fakültesi Dergisi, 6(1), 122-141.

Dağyar, M., ve Demirel, M. (2015). Probleme dayalı öğrenmenin akademik başarıya etkisi: Bir meta-analiz çalışması. Eğitim ve Bilim, 40(181).

Değirmençay, Ş. A. (2010). Zenginleştirilmiş 5E öğretim modeline dayalı rehber materyallerin kavramsal değişim üzerine etkileri:"Isının yayllması ve genleşme".Karadeniz Teknik Üniversitesi, Fen Bilimleri Enstitüsü, Yayınlanmış Doktora Tezi, Trabzon,

Değirmençay, Ş. A., ve Kasap, G. (2013). Okul deneyimi ve öğretmenlik uygulaması derslerine ilişkin öğretmen adaylarının görüşleri. Adnan Menderes Üniversitesi Eğitim Fakültesi Eğitim Bilimleri Dergisi, 4, 47-57. 
Demirel, M., ve Turan, B. A. (2010). Probleme dayalı öğrenmenin başarıya, tutuma, bilişötesi farkındalık ve güdü düzeyine etkisi.Hacettepe Üniversitesi Eğitim Fakültesi Dergisi,38(38), 55-66.

Ferreira, M. M., ve Trudel, A. R. (2012). The impact of problem-based learning (PBL) on student attitudes toward science, problem-solving skills, and sense of community in the classroom. Journal of classroom interaction, 23-30.

Gürlen, E. (2011). Probleme dayalı öğrenmenin öğrenme ürünlerine, problem çözme becerisine, öz-yeterlik alg1 düzeyine etkisi. Hacettepe Üniversitesi Ĕgitim Fakültesi Dergisi, 40(40), 221-232.

Hande, S., Mohammed, C., ve Komattil, R. (2015). Acquisition of knowledge, generic skills and attitudes through problem-based learning: Student perspectives in a hybrid curriculum. Journal of Taibah University Medical Sciences, 10(1), 21-25.

Hiğde, E., ve Aktamış, H. (2017). Fen bilgisi öğretmen adaylarının argümantasyon temelli fen derslerinin incelenmesi: Eylem araştırması. Elementary Education Online, 16(1).

İnel, D. (2009). Fen ve teknoloji dersinde probleme dayal öğrenme yöntemi kullanımının öğrencilerin kavramları yapılandırma düzeyleri, akademik başarıları ve sorgulayıc öğrenme becerileri algılarn üzerindeki etkileri. DEÜ Eğitim Bilimleri Enstitüsü,

İşeri Gökmen, S. (2008). Effects of problem based learning on students' environmental attitude through local vs. non local environmental problems.Unpublishedmaster'sthesis, Middle East Technical University, pp.100, Ankara.

Lin,J.L.,Cheng, M.F., Chang,Y. C., Li, H.W., Chang,J.Y. ve Lin, D.M. (2014),Learning activities that combine science magic activities with the $5 \mathrm{E}$ instructional model to influence secondary-school students' attitudes to science. Eurasia Journal of Mathematics, Science and Technology Education, 10 (5) 415-426

Kumbasar, T. (2019). Probleme dayalı öğretimin farklı öğrenme stilleri ve zeka alanlarına sahip öğrencilerin asitler ve bazlar konusunu öğrenmeleri üzerine etkisi. Marmara Üniversitesi, Eğitim Bilimleri Enstitüsü, Yüksek Lisans Tezi, İstanbul,137.

MEB (2017). İlköğretim Kurumlar Fen Bilimleri (3-8. Sinfflar) Dersi Öğretim Programı. In: Ankara. 
Mapeala, R., ve Siew, N. M. (2016). The development and validation of a thinking maps-aided problem-based learning module for physical science theme of Year 5 Science. International Journal of Current Research, 8(6), 33780-33786

Savaş, S. (2018). Ortaokul 7. Sınıf Türkçe Derslerinde probleme dayalı öğrenmenin öğrenci akademik başarısına etkisi. ZeitschriftfürdieWelt der Türken/Journal of World of Turks, 10(3), 109-125.

Seyhan, M. (2019). Fen eğitiminde probleme dayalı öğretim yönteminin tutum ve başarıya etkisi. Süleyman Demirel Üniversitesi, Eğitim Bilimleri Enstitüsü, Matematik ve Fen Bilimleri Eğitimi Anabilim Dalı, Yüksek Lisans Tezi, Isparta. 98.

Şahin, Y. İ. (2016). Drama tekniğgi ile zenginleştirilmiş 5E öğretim modelinin öğrenci başar ve tutumlarnna yönelik etkileri: Maddenin tanecikli yapısı ve karışımlar. Giresun Üniversitesi Fen Bilimleri Enstitüsü İlköğretim Anabilim Dall,

Şeker, R. (2015). Fen ve teknoloji dersinin işlenişinde probleme dayal öğrenme yönteminin öğrenci başarlarına ve öğrendiklerini hatırlama düzeylerine etkisi. Necmettin Erbakan Üniversitesi, Eğitim Bilimleri Enstitüsü, Yüksek Lisans Tezi, Konya. 75.

Tosun, C., Şenocak, E.,ve Özeken, Ö. (2013). Probleme dayalı öğrenme yönteminin üniversite öğrencilerinin kimya dersine karşı motivasyonlarına ve bilimsel süreç beceri düzeylerine etkisi ve öğrenme ortamı hakkındaki öğrenci görüşleri. Mersin Üniversitesi Eğitim Fakültesi Dergisi, 9(3), 99114.

Turan, B. A. (2014). Probleme dayalı öğrenmenin başarıya, öz-düzenleyici öğrenme becerilerine ve akademik özgüvene etkisi. Hacettepe Üniversitesi, Eğitim Bilimleri Enstitüsü, Doktora Tezi, Ankara. 157.

Uzoğlu, M. (2010). Öğrenme amaçl yazma aktivitelerinin kullanımını ilköğretim seviyesinde kuvvet ve madde ünitesini öğrenmeye etkisinin araşttrnlması.Erzurum Atatürk Üniversitesi, Fen Bilimleri Enstitüsü, Doktora Tezi, Erzurum.

Ünal, K., ve Akay, C. (2017). Öğretmenlik mesleği ve yaşam boyu öğrenme: öğretmen adayları penceresinden. Mersin University Journal of the Faculty of Education, 13(3).

Wong, K. K. H., ve Day, J. R. (2009). A comparative study of problem-based and lecture-based learning in junior secondary school science. Research in Science Education, 39(5), 625-642. 
Yaman, S., ve Yalçın, N. (2005). Fen bilgisi öğretiminde probleme dayalı öğrenme yaklaşımının yaratıcı düşünme becerisine etkisi. Elementary Education Online, 4(1).

Yıldız, N. (2010). Fen eğitiminde probleme dayal öğrenme senaryolarının çözümünde deney uygulamalarmin öğrencilerin başarısına, tutumuna ve bilimsel süreç becerilerine etkisi.Marmara Üniversitesi, Eğitim Bilimleri Enstitüsü, Yüksek Lisans Tezi, , İstanbul. 169.

Yılmaz, F. (2017). İşbirlikli öğrenme jigsaw yöntemiyle yapılan laboratuvar etkinliklerinin ortaokul öğrencilerinin yaşamımızdaki elektrik ünitesindeki başarılarına etkisi. Kafkas Üniversitesi Fen Bilimleri Enstitüsü Matematik ve Fen Bilimleri Eğitimi Anabilim Dalı Fen Bilgisi Eğitimi Bilim Dalı, Kars.

Yılmaz, T. (2016). Probleme dayal öğrenme yönteminin fen konularının öğretilmesinde ortaokul 5. Sinı öğrencilerinin akademik başarnlarnna ve fen bilimleri dersine yönelik tutumlarna etkisi: Işık ve Ses.Fen Bilimleri Enstitüsü,

Zorluoglu, S. L., Sahintürk, A., ve Bagriyanik, K. E. (2017). 2013 Yili Fen Bilimleri Ögretim Programi Kazanimlarinin Yenilenmis Bloom Taksonomisine Göre Analizi ve Degerlendirilmesi/Analysis and Evaluation of Science Course Curriculum Learning Outcomes of the Year 2013 According to the Revised Bloom Taxonomy. Bartin Üniversitesi Egitim Fakültesi Dergisi, 6(1), 1 .

\section{Kaynakça Bilgisi / Citation Information}

Değirmençay, Ş. A. ve Hun, F.(2020).Probleme dayali öğrenme yöntemi ile desteklenen 5e ögretim modelinin başari ve tutuma etkisi. OPUS-Uluslararası Toplum Araştırmaları Dergisi, 16(29), 1689-1717. DOI: 10.26466/opus.754216 